\title{
Kryteria stypendialne i działalność Komisji Stypendialnej na Wydziale Nauk Społecznych Uniwersytetu Gdańskiego
}

Bartosz Duraj | Wydział Nauk Społecznych, Uniwersytet Gdański

Streszczenie

Słowa kluczowe:

kryteria stypendialne,

komisja

stypendialna

doktorat

scholarship criteria,

scholarship

committee, PhD

Student

Studia doktoranckie w Polsce w obecnej formie funkcjonują od 10 lat. W roku akademickim 2014/2015 na polskich uczelniach uczestnikami stacjonarnych studiów było 36458 osób, z czego stypendium doktoranckie pobierały 8004 osoby $(23,2 \%)$, a z dotacji projakościowej korzystały 8753 osoby $(25,4 \%)$. Celem niniejszego artykułu jest podsumowanie działalności komisji stypendialnej działającej na Wydziale Nauk Społecznych Uniwersytetu Gdańskiego oraz wskazanie na istotne zagadnienia w krajowym systemie wsparcia materialnego wpływające na sytuację doktorantów na Wydziale Nauk Społecznych UG.

Scholarship criteria and Scholarship Committee's activity in the Social Studies Department at the Gdansk University

Abstract

Doctoral studies have had its present form for 10 years. In 2014/2015 academic year, there were 36458 stationary students at Polish universities; 8004 of them were given doctoral scholarship $(23,2 \%)$ and another 8753 were using proquality subsidy (25,4\%). The purpose of this article is to sum up the activity of the scholarship committee in the Social Studies Department at the Gdańsk University and indicating some substantial matters connected with the national system of the substantive assistance for doctoral students at the Gdańsk University. 


\section{Wstęp}

Po zmianie ustrojowej na przełomie lat 80. i 90. ubiegłego wieku nastąpił w Polsce gwałtowny wzrost liczby studentów. W okresie boomu edukacyjnego w latach 1980-2010 wzrosła ona prawie pięciokrotnie. Spowodowało to, że współczynnik skolaryzacji netto zwiększył się w tych latach ponad czterokrotnie. Należy jednak zauważyć, że liczba nauczycieli akademickich zwiększyła się w tym samym okresie jedynie 1,5 razy. Na skutek ogromnego wysiłku poniesionego w tym czasie przez szkoły wyższe procentowy wskaźnik populacji w wieku 30-34 lata posiadającej wyższe wykształcenie wyniósł w Polsce w 2012 r. 39,1\% i był nieco wyższy niż średni wskaźnik dla 28 krajów Unii Europejskiej (Sobkowiak 2015: 4).

W Polsce studia doktoranckie funkcjonują od 10 lat. Na polskich uczelniach uczestniczy w nich 40575 osób. W porównaniu z rokiem akademickim 1990/1991 liczba doktorantów wzrosła o ponad 30 tys., a z rokiem 2010/2011 - o 5 tys., jest to więc wzrost znaczący (NIK 2015: 7; KRD 2014: 3; Szkoły wyższe i ich finanse w 2014 r. 2015: 160). W tym miejscu należy podkreślić, że otwarcie przewodu nie musi prowadzić do obrony dysertacji, a przewody mogą również otwierać osoby, które nie są uczestnikami studiów doktoranckich.

Celem niniejszego artykułu jest analiza dotychczasowej działalności komisji stypendialnej na Wydziale Nauk Społecznych Uniwersytetu Gdańskiego w odniesieniu do obowiązującego w Polsce ustawodawstwa oraz wewnętrznych aktów prawnych na UG. W artykule opisane zostaną również przesłanki, na podstawie których udzielane jest stypendium doktoranckie oraz zwiększa się stypendium doktoranckie z dotacji projakościowej.

\section{Ogólny zarys sytemu wsparcia materialnego doktorantów}

W roku akademickim 2014/2015 na polskich uczelniach uczestnikami stacjonarnych studiów doktoranckich (uczestnicy niestacjonarnych studiów nie mogą pobierać stypendium doktoranckiego i korzystać z dotacji projakościowej) było 36458 osób, z czego stypendium doktoranckie pobierały 8004 osoby $(23,2 \%)$, a z dotacji projakościowej 8753 osoby $(25,4 \%)$. Inaczej wyglądała sytuacja wśród doktorantów uniwersytetów: spośród 17611 uczestników studiów stacjonarnych stypendium doktoranckie pobierało 2230 osób (12,7\%), a z dotacji projakościowej korzystało 4630 osób (26,3\%). Wynika z tego, że zaledwie 12,7\% doktorantów na uniwersytetach otrzymuje środki w wysokości 2300 zł (ewentualnie powiększone o stypendium rektora, którego wysokość jest różna w zależności od jednostki). Pozostałe 14\% uzyskuje około 800 zł, a 74\% nie uzyskuje żadnych środków (Szkoły wyższe i ich finanse w 2010 r. 2011: 292, Szkoły wyższe i ich finanse w 2014 r. 2015: 160-161; Bień 2016: 252).

W tym miejscu na uwagę zasługuje pogląd wyrażony w Raporcie Rady Nauki i Szkolnictwa Wyższego: 
Problem pojawia się na etapie ich dystrybucji [stypendiów - przyp. red.]. Brak ograniczeń co do liczby (i kwoty) stypendiów, które jednocześnie może pobierać doktorant, prowadzi do osiągania przez część doktorantów dochodów nie tylko znacznie przekraczających uposażenia oferowane przez krajowy rynek pracy, ale czasami nawet uposażenia ich promotorów. W rezultacie skłania to część osób do celowego przedłużania statusu doktoranta. (...) Studia doktoranckie powinny być postrzegane przez doktoranta jako szansa i inwestycja w siebie, a nie metoda dobrego zarobkowania (jak ma to miejsce w przypadku kumulacji kilku stypendiów) (Sobkowiak 2015: 27).

W literaturze przedmiotu odnaleźć można odmienne stanowisko, uznane za pewną nieprawidłowość, która determinuje bardzo duże dysproporcje w statusie materialnym doktorantów, określane mianem efektu św. Mateusza (Merton 1968):

zjawisko analizowane przez socjologów, w tym socjologów nauki, przejawiające się w interesującym nas kontekście tym, że osoby, które otrzymały stypendia na pierwszym roku, otrzymują je na kolejnych latach studiów. Jest to spowodowane tym, że doktorant, uzyskawszy stypendium, może poświęcić się badaniom, wyjazdom konferencyjnym, pisaniu artykułów, co premiuje go w kolejnym roku. Doktorant, który nie uzyskał świadczeń, zmuszony jest do podjęcia pracy zarobkowej, co często nie pozwala mu na prowadzenie badań i ich prezentację, a przez to uzyskanie punktów niezbędnych do stypendium (Bień 2016: 254).

\section{Działalność komisji stypendialnych na Wydziale Nauk Społecznych Uniwersytetu Gdańskiego}

Funkcjonowanie i działalność wydziałowej doktoranckiej komisji stypendialnej sankcjonuje ustawa Prawo o szkolnictwie wyższym (Dz. U. z 2005 r. Nr 164, poz. 1365 ze zm.) oraz rozporządzenie Ministra Nauki i Szkolnictwa Wyższego z dnia 13 kwietnia 2016 r. w sprawie studiów doktoranckich i stypendiów doktoranckich (Dz. U.z 2016 r., poz. 558). Komisję powołuje rektor uczelni. Przepisy stanowią, że

w skład komisji wchodzi co najmniej 3 nauczycieli akademickich wykonujących pracę w jednostce organizacyjnej uczelni, a w przypadku jednostki naukowej - 3 pracowników naukowych jednostki naukowej, posiadających co najmniej stopień naukowy doktora habilitowanego albo stopień doktora habilitowanego sztuki, albo uprawnienia równoważne z uprawnieniami doktora habilitowanego nabyte na podstawie art. 21a ustawy z dnia 14 marca 2003 r. o stopniach naukowych i tytule naukowym oraz o stopniach i tytule w zakresie sztuki, w tym kierownik studiów doktoranckich, oraz przedstawiciel doktorantów wskazany przez właściwy organ samorządu doktorantów'

W tym miejscu warto zauważyć, że władze Wydziału Nauk Społecznych w porozumieniu z samorządem doktorantów wypracowały własny standard (w granicach obowiązującego prawa), który polega na tym, że członkami wydziałowej doktoranckiej komisji stypendialnej są kierownicy studiów doktoranckich prowadzonych przy Wydziale

\footnotetext{
1 Patrz: § 12 rozporządzenia Ministra Nauki i Szkolnictwa Wyższego z dnia 13 kwietnia 2016 r. w sprawie studiów doktoranckich i stypendiów doktoranckich (Dz. U. z 2016 r., poz. 558).
} 
Nauk Społecznych ${ }^{2}$. Wraz z poszerzaniem przez Wydział oferty naukowo-dydaktycznej w zakresie prowadzonych studiów doktoranckich stosowny organ powołuje do rzeczonej komisji kolejnych kierowników nowoutworzonych studiów. Wypracowana dobra praktyka w tym zakresie przyczyniła się do zobiektywizowania oceny wniosków stypendialnych, pozwoliła również w przypadku wątpliwości (np. interdyscyplinarny charakter osiągnięcia) w sposób możliwie kompetentny rozstrzygać wątpliwości.

Istotną rolę podczas obrad komisji pełni przedstawiciel doktorantów wybierany przez organ samorządu doktorantów Wydziału Nauk Społecznych, czyli przez Wydziałową Radę Doktorantów. Do zadań komisji należy opiniowanie wniosków o przyznanie:

a) stypendium doktoranckiego,

b) zwiększenia stypendium doktoranckiego z dotacji projakościowej³.

W praktyce komisja dokonuje weryfikacji wniosków zarówno pod kątem formalnym, jak i merytorycznym, natomiast decyzję o przyznaniu bądź odmowie przyznania stypendium podejmuje rektor. Komisja po zaopiniowaniu wniosku o przyznanie stypendium doktoranckiego sporządza m.in. listę doktorantów rekomendowanych do przyznania stypendium oraz protokółł.

Na Wydziale Nauk Społecznych funkcjonuje również wydziałowa komisja stypendialna ds. pomocy materialnej dla doktorantów. Powołuje ją spośród pracowników dziekan na wniosek wydziałowej rady doktorantów uniwersytetu oraz doktorantów delegowanych przez wydziałową radę doktorantów. Zgodnie z Regulaminem przyznawania świadczeń pomocy materialnej dla doktorantów na Uniwersytecie Gdańskim uczestnik studiów doktoranckich posiada prawo do otrzymania pomocy materialnej lub innego rodzaju świadczeń ${ }^{5}$. Pomoc materialną może otrzymać w formie stypendium socjalnego, zapomogi, stypendium dla najlepszych doktorantów oraz stypendium specjalnego dla osób niepełnosprawnych. Wydziałowa komisja stypendialna podejmuje decyzję co do przyznania bądź odmowy przyznania wszystkich świadczeń materialnych za wyjątkiem stypendium dla najlepszych doktorantów. W tym wypadku komisja dokonuje stosownej rekomendacji, a decyzję wydaje rektor ${ }^{6}$.

2 Obecnie Wydział Nauk Społecznych prowadzi studia doktoranckie w zakresie psychologii, filozofii, socjologii, politologii oraz pedagogiki.

3 Por. Regulamin przyznawania zwiększenia stypendium doktoranckiego na Uniwersytecie Gdańskim. Tekst ujednolicony z dnia 17 sierpnia 2016 r., stanowiący załącznik do zarządzenia Rektora UG $\mathrm{nr} 71 / \mathrm{R} / 16$.

${ }^{4}$ Komisja musi dopełnić również wielu innych formalności, (zob. rozporządzenie Ministra Nauki i Szkolnictwa Wyższego z dnia 13 kwietnia 2016 r. w sprawie studiów doktoranckich i stypendiów doktoranckich (Dz. U. z 2016 r., poz. 558).

${ }^{5}$ Ponadto doktorant może ubiegać się o zakwaterowanie w hotelu asystenckim UG lub w domu studenckim UG oraz o zakwaterowanie małżonka i dziecka w hotelu asystenckim UG lub w domu studenckim UG.

6 Załącznik nr 1 do zarządzenia Rektora UG nr 86/R/15. 


\section{Kryteria stypendialne}

Doktoranci studiujący na Wydziale Nauk Społecznych mają prawo do ubiegania się o następujące świadczenia materialne:

1. stypendium doktoranckie,

2. zwiększenie stypendium doktoranckiego z dotacji projakościowej,

3. stypendium dla najlepszych doktorantów,

4. stypendium socjalne,

5. stypendium specjalne dla osób niepełnosprawnych,

6. nagrodę rektora,

7. zapomogę.

W tym miejscu skupię się na umówieniu kryteriów stypendium doktoranckiego oraz zwiększenia stypendium doktoranckiego z dotacji projakościowej.

Jedną z najbardziej popularnych form wsparcia materialnego doktorantów jest zwiększenie stypendium doktoranckiego, które może być przyznane na pierwszym roku studiów doktoranckich - doktorantowi, który osiągnął bardzo dobre wyniki w postępowaniu rekrutacyjnym (nie więcej niż 30\% przyjętych doktorantów) oraz na drugim roku i kolejnych latach studiów doktoranckich - doktorantowi, który w roku akademickim poprzedzającym złożenie wniosku o przyznanie zwiększenia stypendium wyróżniał się w pracy naukowej i dydaktycznej oraz w działalności organizacyjnej w tym w samorządzie doktorantów - bezpośrednio związanej z pracą naukową lub dydaktyczną (nie więcej niż 30\% najlepszych doktorantów na poszczególnych latach studiów doktoranckich). Wydziały prowadzące studia doktoranckie posiadają szczegółowe i specyficzne kryteria stypendialne determinowane w większości przypadków przez specyfikę prowadzonych badań naukowych. Wydział Nauk Społecznych dla wszystkich prowadzonych studiów doktoranckich posiada jednolite kryteria stypendialne. W tym miejscu należy rozważyć zasadność jednakowej oceny np. doktorantów psychologii z doktorantami nauk politycznych. Specyfika tych dyscyplin jest tak duża, że w odniesieniu do czasopism i ich wartości punktowych możliwość opublikowania przez politologów artykułu w międzynarodowych, wysoko punktowanych periodykach jest znacznie ograniczona. Niestety, postulowana rekomendacja zmian nie może zostać wprowadzona ze względu na ograniczenia wynikające $z$ wewnętrznych aktów prawnych UG.

Kryteria przyznawania stypendiów dla doktorantów można podzielić na dwie grupy (zob. tab. 1., Aneks). Pierwsza z nich to kryteria dla doktorantów będących na pierwszym roku studiów doktoranckich. Komisja bada, czy doktorant osiągnął bardzo dobre wyniki w postępowaniu rekrutacyjnym. W tym miejscu należy zaznaczyć, że stypendium nie jest przyznawane automatycznie - doktorant zobligowany jest do złożenia wniosku wraz z dokumentem potwierdzającym lokatę na liście rankingowej (np. skan listy rankingowej potwierdzonej za zgodność z oryginałem przez pracownika dziekanatu). Hipotetycznie możliwa jest również sytuacja, w której stypendium to otrzyma 
osoba przyjęta na studia z ostatniego miejsca na liście rankingowej , jednak przy założeniu, że osoby posiadające wyższe lokaty takiego wniosku nie złożą. Druga grupa to kryteria dla doktorantów będących na drugim roku i kolejnych latach studiów doktoranckich. Przedmiotem badania komisji jest to, czy doktorant złożył sprawozdanie z pracy naukowej w roku akademickim poprzedzającym złożenie wniosku. Winno być ono zaakceptowane przez opiekuna naukowego lub promotora. Kryterium to jest niepunktowane - stanowi przesłankę obligatoryjną, bez spełnienia której komisja nie może rozpatrywać innych. Następnie komisja weryfikuje to, czy doktorant wyróżniał się w pracy naukowej. Za aktywny udział w konferencji naukowej (referat lub/i plakat) można uzyskać od 2 do 3 pkt w zależności od rodzaju i skali konferencji. Regulamin nie precyzuje maksymalnej liczby konferencji, na których doktorant może wykazywać się aktywnością. Działalność związana z publikacjami (tylko w naukowych recenzowanych czasopismach i wydawnictwach książkowych) oceniana jest w następujący sposób: recenzowana monografia wydana w naukowym wydawnictwie zagranicznym - za każdą monografię autor otrzymuje 30 pkt, a współautor 20 pkt; recenzowana monografia wydana w naukowym wydawnictwie polskim - za każdą monografię autor otrzymuje 20 pkt, a współautor - 15 pkt). Za redakcję książki obcojęzycznej w z zależności od tego, czy została ona wydana w wydawnictwie krajowym, czy też zagranicznym, regulamin przewiduje od 7 do 12 pkt. Za artykuł w recenzowanym czasopiśmie zagranicznym lub rozdział w recenzowanej zagranicznej pracy zbiorowej można uzyskać 10 pkt lub liczbę punktów zgodną z zasadami punktacji określonymi przez Ministerstwo Nauki i Szkolnictwa Wyższego, obowiązującymi w dniu 20 października roku akademickiego, jeśli te zasady przewidują wyższą punktację. Za każdy artykuł w naukowych czasopismach ogólnopolskich przyznaje się liczbę punktów zgodnie z zasadami punktacji określonymi przez MNiSW. Regulamin dopuszcza również uzyskanie 2 pkt za każdy artykuł w recenzowanym czasopiśmie polskim (za publikację, w której nie są przyznawane punkty) lub każdy rozdział w recenzowanej pracy zbiorowej w języku polskim. Najwięcej kontrowersji podczas obrad komisji budził punkt dotyczący oceny recenzji, komunikatu i sprawozdania. Przed zmianą regulaminu doktorant mógł uzyskać bardzo dużą liczbę punktów nawet za działalność, która nie miała najmniejszego związku z realizacją zamierzeń naukowych, np. wpis na stronę internetową, wpis na blog popularnonaukowy itp., dlatego na wniosek komisji wprowadzono zmiany i obowiązujący regulamin pozwala na otrzymanie maksymalnie 3 punktów także w tej kategorii.

Wnioskodawca może również uzyskać punkty za odbyty staż naukowy na uczelni oraz instytucji naukowej w Polsce i za granicą oraz każdej innej niż naukowa, jeżeli związana jest ona z realizacją badań doktorskich. Za taką formę aktywności naukowej uzyskać można od 2 pkt do 5 pkt, jeżeli staż trwa co najmniej pełen miesiąc. Ważną rolę w rozwoju młodego adepta nauki pełnią granty na realizację projektów badawczych lub badawczo-rozwojowych. W stosunku do innych kategorii oceniane są bardzo wysoko, ponadto stanowią asumpt do podnoszenia jakości realizowanych badań naukowych. Kryteria stypendialne rozróżniają cztery stanowiska (funkcje) 
w projektach grantowych, za które można otrzymać punkty. Są to: kierownik projektu, główny wykonawca, pracownik pomocniczy oraz wykonawca w projekcie. Podczas oceny wniosków stypendialnych można zaobserwować, że praca i chęć pozyskiwania grantów z roku na rok jest coraz bardziej powszechna. W zależności od charakteru grantu i stanowiska można uzyskać aż 22 pkt (stanowisko kierownika projektu - grant międzynarodowy), $5 \mathrm{pkt}$ - stanowisko kierownika (grant uczelniany), stanowisko pracownika pomocniczego lub wykonawcy w projekcie -1 pkt.

Doktorant, który wyróżnia się w pracy dydaktycznej, może uzyskać punkty w dwóch kategoriach, tj. samodzielne prowadzenie zajęć powyżej 61 godzin dydaktycznych 3 pkt; do 30 godzin dydaktycznych - 1 pkt. Oceniana jest również inna działalność dydaktyczna (wykłady i warsztaty otwarte, zajęcia popularyzatorskie w UG i poza UG) 1 pkt za przeprowadzenie każdego cyklu zajęć w wymiarze min. 6 godzin dydaktycznych. Pod tym względem doktoranci Wydziału Nauk Społecznych są bardzo aktywni. Na uwagę zasługuje to, że wielu z nich włącza się organizację Bałtyckiego Festiwalu Nauki pro publico bono; prócz tego realizują warsztaty i zajęcia w liceach ogólnokształcących oraz organizacjach pozarządowych.

Uwarunkowania demograficzne, zmienne zainteresowanie ofertą dydaktyczną, a także sytuacja finansowa Wydziału sprawia, że praktyka dydaktyczna realizowana przez doktorantów budzi wiele kontrowersji. Z jednej strony jest ona warunkiem obligatoryjnym do prawidłowego zaliczenia roku akademickiego, z drugiej zaś dla władz poszczególnych Instytutów stanowi istotny problem. Kierownicy instytutów, na których prowadzone są "niskopopytowe" kierunki, cieszące się mniejszą popularnością, zobligowani są do takiego rozplanowania zajęć, by pracownicy macierzystych jednostek mogli wykonać pensum, a doktoranci w minimalnym wymiarze realizować praktyki. Wszystko to ma bardzo duży wpływ na przygotowanie doktorantów do samodzielnego prowadzenia zajęć.

Podczas oceny brana jest również pod uwagę działalność organizacyjna w samorządzie doktorantów bezpośrednio związana z pracą naukową i dydaktyczną. Za aktywną działalność $w$ komitecie redakcyjnym publikacji albo $w$ komitecie naukowym lub organizacyjnym konferencji bądź też innego znaczącego wydarzenia naukowego w zależności od szczebla (międzynarodowy, krajowy, macierzystej uczelni) łącznie za wszystkie kategorie komisja może przyznać maksymalnie 6 pkt. Za działalność samorządową wnioskodawca w zależności od szczebla (jak wyżej) może uzyskać łącznie za wszystkie kategorie maksymalnie 6 pkt.

Stypendium doktoranckie dla doktorantów pierwszego roku na Wydziale Nauk Społecznych może być przyznane doktorantowi, który osiągnął bardzo dobre wyniki w postępowaniu rekrutacyjnym. Doktoranci na drugim roku i kolejnych latach studiów mogą uzyskać stypendium, jeżeli m.in. terminowo ${ }^{1}$ realizują ich program. Doktorant

\footnotetext{
1 Za terminową realizację programu studiów uznaje się uzyskanie w roku akademickim poprzedzającym złożenie wniosku zaliczeń i egzaminów z przedmiotów, do których przypisano co najmniej 2/3 punktów ECTS przewidzianych do uzyskania w danym roku studiów doktoranckich. W przypadku
} 
winien wykazywać się samodzielnym prowadzeniem zajęć dydaktycznych w ramach praktyk zawodowych, za które w zależności od wymiaru godzinowego może uzyskać od 1 do 3 pkt albo realizacją badań naukowych prowadzonych przez wydział. Granty na realizację projektów badawczych lub badawczo-wdrożeniowych realizowanych na Wydziale oceniane są w następujący sposób: grant międzynarodowy - stanowisko kierownika projektu 15 pkt, stanowisko głównego wykonawcy - 10 pkt; grant krajowy - stanowisko kierownika projektu 12 pkt, stanowisko głównego wykonawcy - 7 pkt; grant uczelniany ${ }^{2}$ - stanowisko kierownika projektu 5 pkt, inne stanowiska, np. pracownika pomocniczego - 1 pkt. Wnioskodawca wykazujący się inną działalnością związaną z realizacją badań naukowych na Wydziale może uzyskać punkty za udział w przygotowaniu wydarzeń lub publikacji naukowych w zależności od rangi wydarzenia, np. za wydarzenia organizowane przez jednostki organizacyjne UG lub instytucje regionalne na rzecz UG lub regionu - 1 pkt, wydarzenia i publikacje międzynarodowe -3 pkt, jednak nie więcej niż 6 punktów za podkategorię. Oceniana jest również praca w zespole badawczym realizującym badania statutowe. Za pracę w charakterze pomocniczym i technicznym uzyskać można 1 pkt, zaś za realizację badań badawczych 2 pkt, jednak nie więcej niż 5 pkt w całej podkategorii.

Kolejną przesłanką istotną z punktu procedowania wniosku stypendialnego jest weryfikacja, czy doktorant wykazuje się postępami w pracy naukowej i w przygotowywaniu rozprawy doktorskiej. Wszczęcie przewodu doktorskiego punktowane jest na poziomie 5 pkt, jednak punkty te mogą być przyznane tylko jeden raz podczas studiów doktoranckich. Udział w konferencjach naukowych - za referat lub plakat na konferencji międzynarodowej za granicą uzyskać można 5 pkt. Regulamin nie określa limitu referatów i plakatów, które mogą zostać zaprezentowane podczas jednej konferencji naukowej. W przypadku referatu lub plakatu na konferencji międzynarodowej w Polsce są to 3 pkt za każdy referat lub plakat, pod uwagę brana jest również aktywna działalność konferencyjna w kraju - tu można otrzymać 2 pkt za każdy referat lub plakat. Publikacje naukowe wydane w naukowych recenzowanych czasopismach naukowych i wydawnictwach książkowych są kategoryzowane i punktowane w taki sam sposób, jak w przypadku kryteriów zwiększenia stypendium doktoranckiego. W przypadku staży naukowych również możemy mówić o podobnych przesłankach oraz punktacji, jak w przypadku zwiększenia stypendium. Zaangażowanie w przedsięwzięcia społeczne, samorządowe oraz popularnonaukowe, choć bardzo cenne, nie jest brane pod uwagę podczas oceny wniosku o przyznanie stypendium doktoranckiego.

doktoranta, któremu przedłużono okres odbywania studiów doktoranckich, za terminową realizację programu studiów uznaje się uzyskanie zaliczeń i egzaminów ze wszystkich przedmiotów przewidzianych w programie studiów (Załącznik do zarządzenia Rektora UG nr 87/R/15 ze zm.).

2 Projekty badawcze dla młodych naukowców oraz uczestników studiów doktoranckich 


\section{Podsumowanie}

Na podstawie analizy systemu wsparcia materialnego doktorantów będących uczestnikami studiów doktoranckich na polskich uczelniach oraz na Wydziale Nauk Społecznych widoczny jest brak systemowych rozwiązań, które mogły stymulować i pozytywnie motywować doktorantów do pracy w zawodach akademickich. Pomimo tego że kryteria stypendialne w dużym stopniu zależą od uczelni i doktorantów (samorządy mają wpływ na tworzenie zapisów), w dużej mierze determinują one zjawiska, które nie przekładają się na wysoką jakość pracy naukowej. Wśród zjawisk budzących poważne zastrzeżenia wyróżnić możemy np. równe punktowanie artykułów w czasopismach znajdujących się w wykazie czasopism naukowych, publikacji w pozycjach wydawanych przez ministra nauki i szkolnictwa wyższego oraz artykułów z mniej znaczących periodyków (popularnonaukowych lub innych, niemających charakteru naukowego) (Dokowicz i in. 2014; KRD 2014: 7; Kulczycki 2015; Wawrzyński 2015, Bień 2016: 254). Wspominany w tekście efekt św. Mateusza stanowi bardzo istotny problem i w moim mniemaniu może mieć decydujący wpływ na karierę młodego badacza. Od wielu lat Krajowa Reprezentacja Doktorantów oraz Doktoranckie Forum Uniwersytetów Polskich postuluje, aby każdy nowo przyjęty uczestnik studiów doktoranckich otrzymał wsparcie finansowe w postaci stypendium doktoranckiego. Rzetelna praca badawcza nie może być przerywana przez prace sezonowe lub inne formy zarobku, które nie mają związku z zainteresowaniami badawczymi doktoranta. Wydaje się, że ów postulat coraz częściej brany jest pod uwagę przez decydentów. $Z$ doniesień medialnych wynika, że minister nauki i szkolnictwa wyższego popiera ów pomysł (Orłowski 2017).

Kluczową rolę w przeobrażeniach polskiego systemu szkolnictwa wyższego, w tym studiów doktoranckich, stanowić będzie Ustawa 2.0. Ukazane w niej założenia dotyczące funkcjonowania studiów doktoranckich w Polsce są nowatorskie i mogą być asumptem do realnej zmiany sytuacji materialnej młodych adeptów nauki, a przede wszystkim przyczynić się do zwiększenia jakości dysertacji doktorskich oraz liczby obronionych doktoratów w stosunku do liczby uczestników studiów doktoranckich. Resort nauki przymierza się też do przebudowy modelu kształcenia doktorantów. W maju 2017 r. zapowiedział on, że chce wprowadzić trzy ścieżki uzyskiwania doktoratu. Pierwsza z nich to udział w programach doktorskich prowadzonych na poziomie uczelni bądź struktur międzyuczelnianych. Druga miałaby charakter eksternistyczny, trzecia z kolei dotyczyłaby grantów w konkursie Narodowego Centrum Nauki dla wybitnych doktorantów i promotorów (PAP 2017). Kolejnym novum są sprawy zabezpieczenia stypendialnego. W doniesień prasowych wynika, że ministerstwo popiera postulat doktorantów o objęcie stypendium wszystkich uczestników studiów. Początkujący doktorant ma otrzymać 110 proc. płacy minimalnej - to dziś ok. 2 tys. zł. Po dwóch latach, gdy jego postępy w pracy zostaną ocenione przez specjalną komisję, stypendium wzrosłoby do 170 proc. płacy minimalnej (BIP 2017). 


\section{Aneks:}

Tab. 1. Szczegółowe kryteria przyznawania zwiększenia stypendium doktoranckiego na wydziale nauk społecznych

\begin{tabular}{|c|c|c|}
\hline $\begin{array}{l}\text { I Kryteria dla doktoran- } \\
\text { tów na pierwszym roku } \\
\text { studiów doktoranckich }\end{array}$ & $\begin{array}{l}\text { Osiągnął bardzo dobre } \\
\text { wyniki w postępowa- } \\
\text { niu rekrutacyjnym }\end{array}$ & $\begin{array}{l}\text { Na pierwszym roku studiów doktoranckich zwiększenie stypen- } \\
\text { dium doktoranckiego może być przyznane doktorantowi, który } \\
\text { osiągnął bardzo dobre wyniki w postępowaniu rekrutacyjnym. }\end{array}$ \\
\hline $\begin{array}{l}\text { II Kryteria dla dok- } \\
\text { torantów na drugim } \\
\text { roku i kolejnych latach } \\
\text { studiów doktoranckich }\end{array}$ & $\begin{array}{l}\text { a) Wyróżnianie się } \\
\text { w pracy naukowej }\end{array}$ & 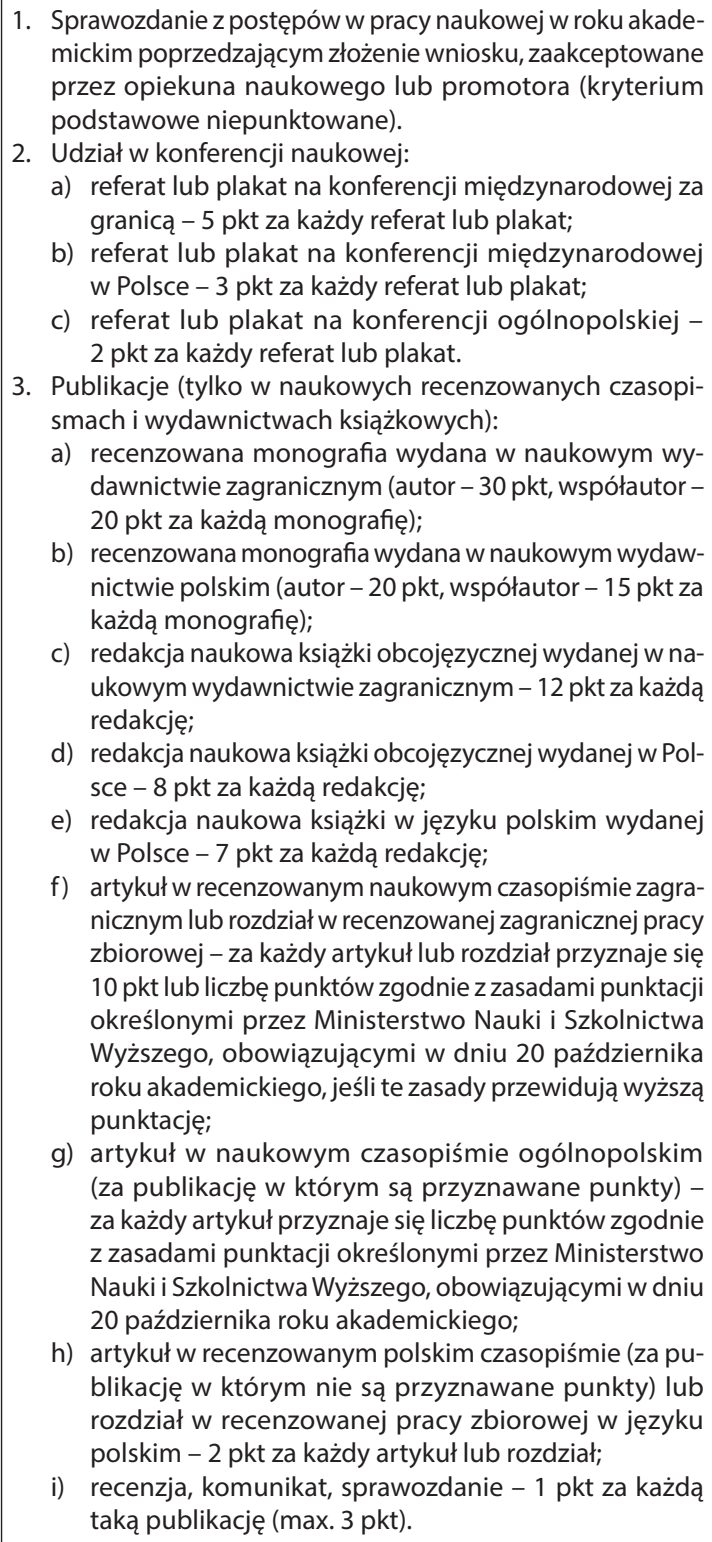 \\
\hline
\end{tabular}




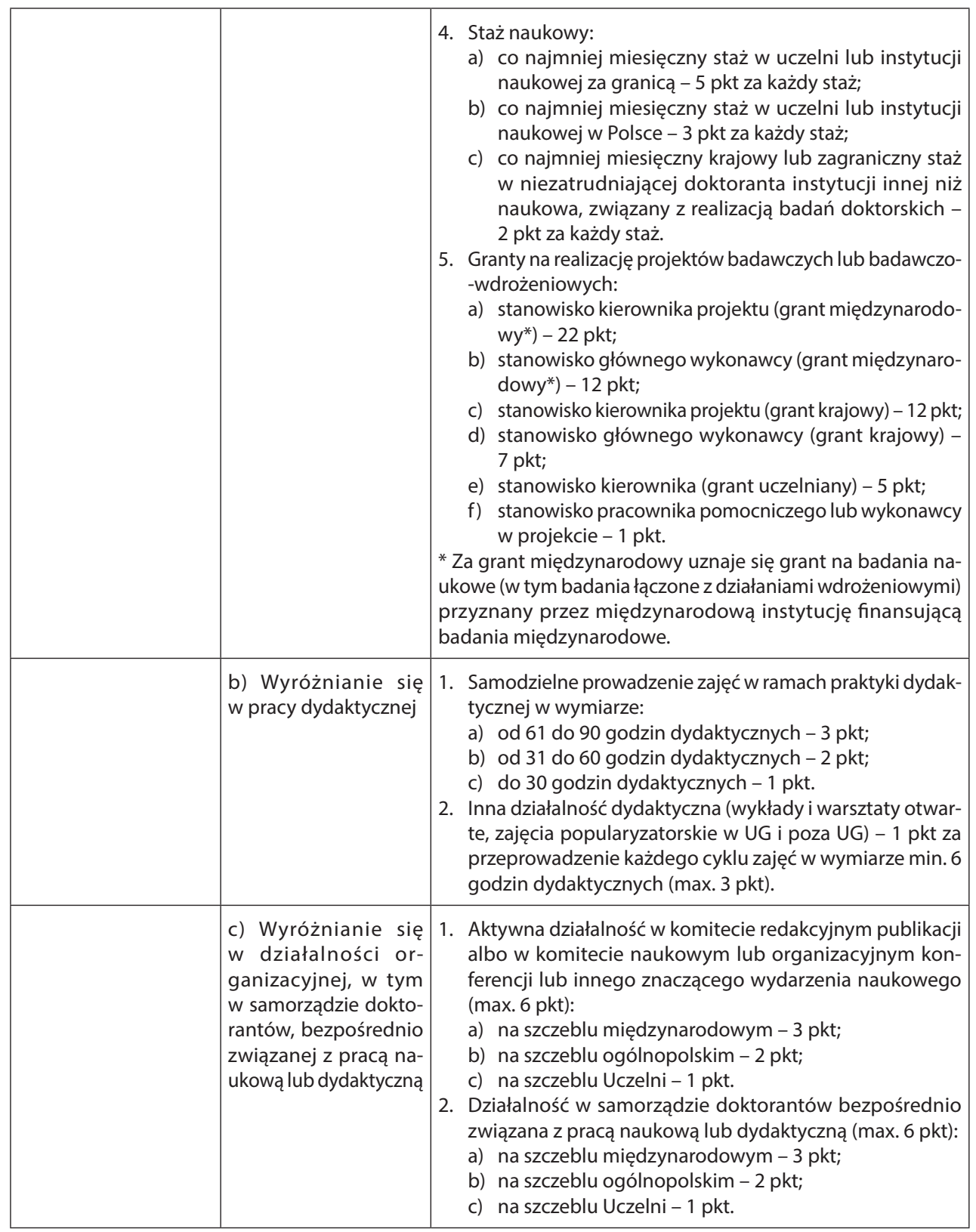


III Sposób udokumentowania spełnienia kryteriów
1. Osiągnięcie bardzo dobrych wyników w postępowaniu rekrutacyjnym stwierdza się na podstawie protokołu dokumentującego przebieg postępowania rekrutacyjnego w sprawie danego kandydata.

2. Ad Ila) 1 - do wniosku należy dołączyć kopię zaakceptowanego sprawozdania z postępów w pracy naukowej za rok akademicki poprzedzający złożenie wniosku.

3. Ad Ila) 2 - do wniosku należy dołączyć zaświadczenie o udziale w konferencji określające tytuł wygłoszonego referatu lub komunikatu lub tytuł przedstawionego plakatu oraz kopię programu konferencji.

4. Ad lla) 3 - do wniosku należy dołączyć odpowiednio:

- wykaz osiągnięć naukowych zgłoszonych we wniosku wraz z punktacją - samodzielnie obliczoną przez wnioskodawcę - przysługującą w związku ze zgłoszeniem tych osiągnięć;

- kopię stron tytułowych publikacji (w przypadku publikacji w czasopiśmie zawierających również informacje dotyczące czasopisma), a w przypadku publikacji książkowych lub czasopism nie podających informacji dotyczących czasopisma na stronie tytułowej artykułu - także kopię stron zawierających informacje dotyczące czasopisma lub książki wraz z kopią spisu treści, natomiast w przypadku książek - również kopię stron zawierających informacje o recenzji publikacji;

- jeśli zgłaszana publikacja jeszcze się nie ukazała - zaświadczenie wydawcy o przyjęciu jej do druku.

5. Ad Ila) 4-do wniosku należy dołączyć kopię zaświadczenia o odbyciu stażu, wystawionego przez uczelnię lub instytucję przyjmującą na staż, wraz z poświadczonym opisem zrealizowanych badań.

6. Ad Ila) 5 - do wniosku należy dołączyć kopię zaświadczenia o uzyskanym grancie lub - w przypadku udziału w realizacji projektu - oświadczenie kierownika projektu.

7. Ad Ilb) 1 - do wniosku należy dołączyć kopię odpowiednich stron indeksu zawierających potwierdzenie zaliczenia praktyk dydaktycznych.

8. Ad Ilb) 2 - do wniosku należy dołączyć zaświadczenie wystawione przez dyrektora instytutu, dziekanat lub inną instytucję, potwierdzające zrealizowanie zajęć dydaktycznych innych niż związane z indywidualną praktyką dydaktyczną.

9. Zgłoszone we wniosku osiągnięcia dotyczące wyróżniania się w działalności organizacyjnej, w tym w samorządzie doktorantów, bezpośrednio związanej z pracą naukową lub dydaktyczną, należy odpowiednio udokumentować. W przypadku aktywnej działalności w komitecie redakcyjnym publikacji albo w komitecie naukowym lub organizacyjnym konferencji lub innego znaczącego wydarzenia naukowego do wniosku należy dołączyć kopię zaświadczenia o rodzaju i zakresie działań podejmowanych przez doktoranta.

Źródło: Załącznik nr 2 do zarządzenia Rektora UG nr 88/R/15 ze zm. 
Tab. 2. Szczegółowe kryteria przyznawania stypendium doktoranckiego na wydziale nauk społecznych

\begin{tabular}{|c|c|c|}
\hline $\begin{array}{l}\text { I Kryteria dla doktoran- } \\
\text { tów na pierwszym roku } \\
\text { studiów doktoranckich }\end{array}$ & $\begin{array}{l}\text { Osiągnął bardzo dobre } \\
\text { wyniki w postępowa- } \\
\text { niu rekrutacyjnym }\end{array}$ & $\begin{array}{l}\text { Na pierwszym roku studiów doktoranckich stypendium dok- } \\
\text { toranckie może być przyznane doktorantowi, który osiągnął } \\
\text { bardzo dobre wyniki w postępowaniu rekrutacyjnym. }\end{array}$ \\
\hline \multirow[t]{5}{*}{$\begin{array}{l}\text { Il Kryteria dla dok- } \\
\text { torantów na drugim } \\
\text { roku i kolejnych latach } \\
\text { studiów doktoranckich }\end{array}$} & $\begin{array}{l}\text { 1. Terminowo realizu- } \\
\text { je program studiów }\end{array}$ & $\begin{array}{l}\text { Za terminową realizację programu studiów uznaje się uzyska- } \\
\text { nie, w roku akademickim poprzedzającym złożenie wniosku, } \\
\text { zaliczeń i egzaminów z przedmiotów, do których przypisano } \\
\text { co najmniej } 2 / 3 \text { punktów ECTS przewidzianych do uzyskania } \\
\text { w danym roku studiów doktoranckich. } \\
\text { W przypadku doktoranta, któremu przedłużono okres odbywa- } \\
\text { nia studiów doktoranckich, za terminową realizację programu } \\
\text { studiów uznaje się uzyskanie zaliczeń i egzaminów ze wszyst- } \\
\text { kich przedmiotów przewidzianych w programie studiów. }\end{array}$ \\
\hline & \multicolumn{2}{|c|}{ 2. Wykazuje się zaangażowaniem: } \\
\hline & $\begin{array}{l}\text { a) w prowadzeniu za- } \\
\text { jęć dydaktycznych } \\
\text { w ramach praktyk } \\
\text { zawodowych }\end{array}$ & $\begin{array}{l}\text { Prowadzenie samodzielnych zajęć w ramach praktyki dydak- } \\
\text { tycznej w wymiarze: } \\
\text { a) Od } 61 \text { do } 90 \text { godz. - } 3 \text { pkt; } \\
\text { b) Od } 31 \text { do } 60 \text { godz. - } 2 \text { pkt; } \\
\text { c) Do } 30 \text { godz. - } 1 \text { pkt. }\end{array}$ \\
\hline & \multicolumn{2}{|l|}{ Albo } \\
\hline & $\begin{array}{l}\text { b) w realizacji badań } \\
\text { naukowych pro- } \\
\text { wadzonych przez } \\
\text { wydział }\end{array}$ & $\begin{array}{l}\text { 1. Granty na realizację projektów badawczych lub badawczo- } \\
\text {-wdrożeniowych realizowanych na wydziale: } \\
\text { a) Stanowisko kierownika projektu (grant międzynarodo- } \\
\text { wy*) - } 15 \text { pkt; } \\
\text { b) Stanowisko głównego wykonawcy (grant międzynaro- } \\
\text { dowy*) - } 10 \text { pkt; } \\
\text { c) Stanowisko kierownika projektu (grant krajowy) - } 12 \text { pkt; } \\
\text { d) Stanowisko głównego wykonawcy (grant krajowy) - } \\
7 \text { pkt; } \\
\text { e) Stanowisko kierownika (grant uczelniany) - } 5 \text { pkt; } \\
\text { f) Stanowisko pracownika pomocniczego lub wykonawcy } \\
\text { w projekcie - } 1 \text { pkt. } \\
\text { * za grant międzynarodowy uznaje się grant na badania na- } \\
\text { ukowe (w tym badania łączone z działaniami wdrożeniowymi) } \\
\text { przyznany przez międzynarodową instytucję finansującą } \\
\text { badania międzynarodowe. } \\
\text { 2. Inna działalność związana z realizacją badań naukowych } \\
\text { na wydziale: } \\
\text { a) Udział w przygotowaniu wydarzeń lub publikacji na- } \\
\text { ukowych (np. prace techniczne lub redakcyjne albo } \\
\text { tłumaczenia) - max. } 6 \text { pkt: } \\
\text { - wydarzenia i publikacje międzynarodowe - } 3 \text { pkt, } \\
\text { - wydarzenia i publikacje ogólnopolskie - } 2 \text { pkt, } \\
\text { - wydarzenia organizowane przez jednostki organi- } \\
\text { zacyjne ug lub instytucje regionalne na rzecz ug lub } \\
\text { regionu - } 1 \text { pkt; } \\
\text { b) Praca w zespole badawczym realizującym badania } \\
\text { statutowe (max. } 6 \text { pkt): } \\
\text { - realizacja zadań badawczych - } 2 \text { pkt, } \\
\text { - praca o charakterze pomocniczym i technicznym - } \\
1 \text { pkt. }\end{array}$ \\
\hline
\end{tabular}


3. Wykazuje się postępami w pracy naukowej i w przygotowywaniu rozprawy doktorskiej
1. Otwarcie przewodu doktorskiego -5 pkt (punkty za otwarcie przewodu doktorskiego przyznaje się tylko raz w całym okresie studiów doktoranckich).

2. Udział w konferencjach naukowych:

a) referat lub plakat na konferencji międzynarodowej za granicą - 5 pkt za każdy referat lub plakat;

b) referat lub plakat na konferencji międzynarodowej w Polsce - 3 pkt za każdy referat lub plakat;

c) referat lub plakat na konferencji ogólnopolskiej 2 pkt za każdy referat lub plakat.

3. Publikacje (tylko w naukowych recenzowanych czasopismach i wydawnictwach książkowych):

a) recenzowana monografia wydana w naukowym wydawnictwie zagranicznym (autor - 30 pkt, współautor 20 pkt, za każdą monografię);

b) recenzowana monografia wydana w naukowym wydawnictwie polskim (autor - 20 pkt, współautor - 15 pkt, za każdą monografię);

c) redakcja naukowa książki obcojęzycznej wydanej w wydawnictwie zagranicznym - 12 pkt za każdą redakcję;

d) redakcja naukowa książki obcojęzycznej wydanej w Polsce - 8 pkt za każdą redakcję;

e) redakcja naukowa książki wydanej w języku polskim 7 pkt za każdą redakcję;

f) artykuł w recenzowanym naukowym czasopiśmie zagranicznym lub rozdział $w$ recenzowanej zagranicznej pracy zbiorowej - za każdy artykuł lub rozdział przyznaje się 10 pkt lub liczbę punktów zgodnie z zasadami punktacji określonymi przez Ministerstwo Nauki i Szkolnictwa Wyższego, obowiązującymi w dniu 20 października roku akademickiego, jeśli te zasady przewidują wyższą punktację;

g) artykuł w naukowym czasopiśmie ogólnopolskim (za publikację w którym są przyznawane punkty) - za każdy artykuł przyznaje się liczbę punktów zgodnie z zasadami punktacji określonymi przez Ministerstwo Nauki i Szkolnictwa, obowiązującymi w dniu 20 października roku akademickiego;

h) artykuł w recenzowanym polskim czasopiśmie (za publikację w którym nie są przyznawane punkty) lub rozdział w recenzowanej pracy zbiorowej w języku polskim - 2 pkt za każdy artykuł lub rozdział;

i) recenzja, komunikat, sprawozdanie - 1 pkt za każdą taką publikację (max. 3 pkt).

4. Staż naukowy:

a) co najmniej miesięczny staż w uczelni lub instytucji naukowej za granicą - 5 pkt za każdy staż;

b) co najmniej miesięczny staż w uczelni lub instytucji naukowej w Polsce - 3 pkt za każdy staż;

c) co najmniej miesięczny krajowy lub zagraniczny staż w niezatrudniającej doktoranta instytucji innej niż naukowa, związany z realizacją badań doktorskich 2 pkt za każdy staż. 


\begin{tabular}{|c|c|}
\hline $\begin{array}{l}\text { III Sposób udokumen- } \\
\text { towania spełnienia } \\
\text { kryteriów }\end{array}$ & 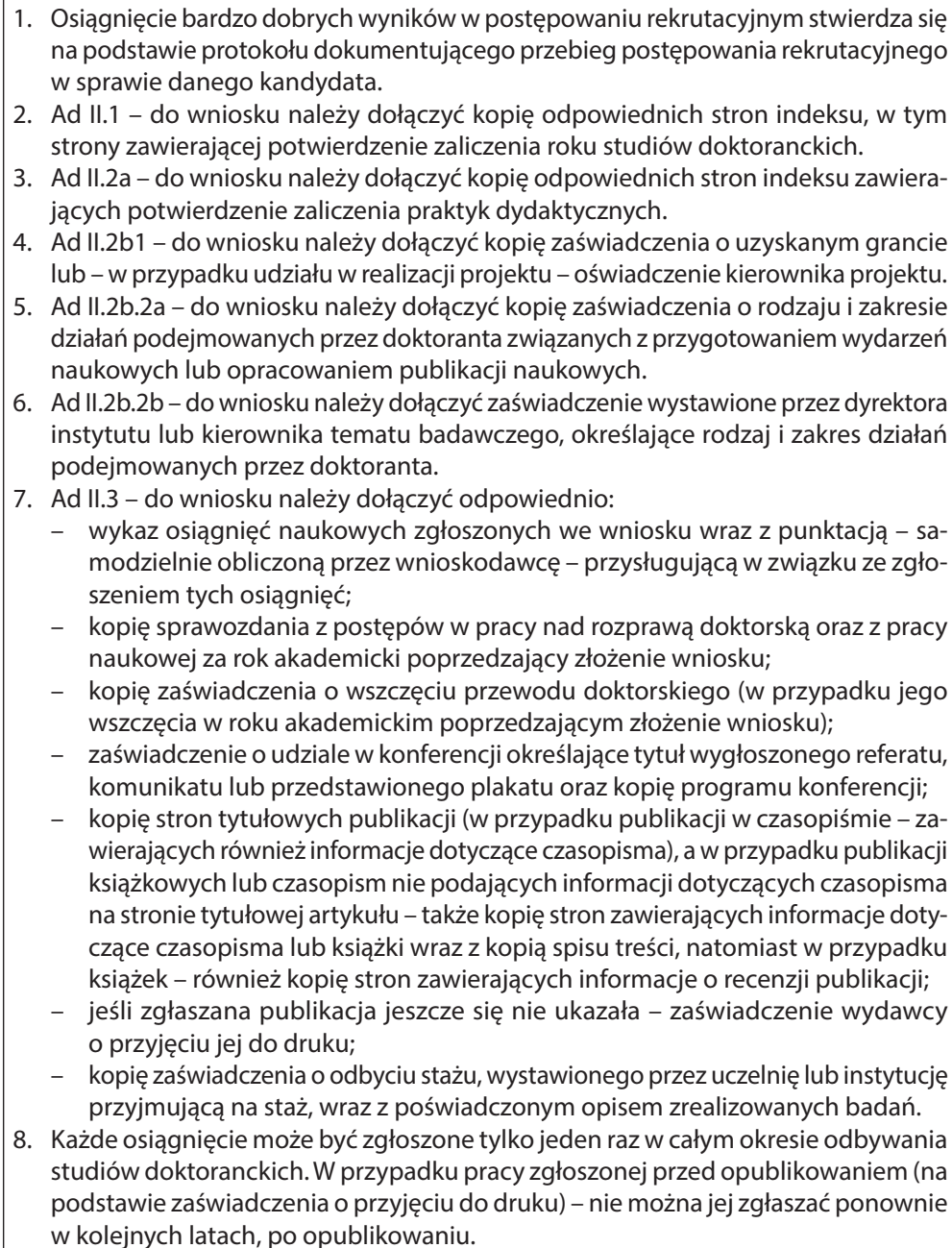 \\
\hline
\end{tabular}

Źródło: Załącznik nr 2 do zarządzenia Rektora UG nr 88/R/15 ze zm.

\section{Literatura}

Bień D., 2016, Studia trzeciego stopnia w polskich uczelniach - funkcjonowanie, diagnoza, rekomendacje, "Nauka i Szkolnictwo Wyższe” 1(47).

Szkoły wyższe i ich finanse w 2010 r., 2011, Warszawa: Główny Urząd Statystyczny.

Szkoły wyższe i ich finanse w 2014 r., 2015, Warszawa: Główny Urząd Statystyczny.

Kowzan P., Krzymiński D., 2012, Pomiędzy alienacja a emancypacja: rola rad doktoranckich w ustalaniu pozycji doktorantów na przykładzie Uniwersytetu Gdańskiego (w:) Uniwersytet i emancypacja, red. M. Trawińska, M. Maciejewska, Wrocław: Interdyscyplinarna Grupa Gender Studies. 
Krajowa Reprezentacja Doktorantów, 2014, Opis nieprawidłowości i zjawisk patologicznych na studiach doktoranckich, http://samorzaddoktorantow.pan.pl/wp-content/uploads/2014/10/Zjawiska-Patologiczne-na-Studiach-Doktoranckich.pdf [dostęp: 26.05.2017].

Kraśniewski A., 2009, Kształcenie (w:) Polskie Szkolnictwo wyższe. Stan, uwarunkowania i perspektywy, red. R.Z. Morawski, Warszawa: Wydawnictwa Uniwersytetu Warszawskiego.

Kulczycki E., 2015, Drapieżne konferencje w Polsce. Robienie w balona czy „f forma oporu"? http://ekulczycki.pl/warsztat_badacza/drapiezne-konferencje-w-polsce-robieniew-balona-czy-forma-oporu/ [dostęp: 26.05.2017].

Merton R., 1968, The Matthew Effect in Science, ,'Science", 159(3810).

Najwyższa Izba Kontroli, 2015, Informacja o wynikach kontroli. Kształcenie na studiach doktoranckich https://www.nik.gov.pl/plik/id,9897,vp,12191.pdf [dostęp: 26.05.2017].

Orłowski M., 2017, Każdy doktorant ze stypendium? Minister Gowin jest za, http://wyborcza. pl/7,75398,21844998,kazdy-doktorant-ze-stypendium-minister-gowin-jest-za.html?disableRedirects=true [dostęp: 26.05.2017].

Polska Agencja Prasowa, 2017, Ustawa 2.0 nabiera kształtów - zmiany na uczelniach w zapowiedziach MNiSW http://naukawpolsce.pap.pl/aktualnosci/news\%2C414176\%2Custawa-20-nabiera-ksztaltowzmiany-na- uczelniach-w- zapowiedziach-mnisw.html [dostęp: 01.09.2017].

Rozporządzenie, 2016, Rozporządzenia Ministra Nauki i Szkolnictwa Wyższego z dnia 13 kwietnia 2016 r. w sprawie studiów doktoranckich i stypendiów doktoranckich (Dz. U. z 2016 r., poz. 558).

Regulamin, 2016b, Regulamin przyznawania zwiększania stypendium doktoranckiego w Uniwersytecie Gdańskim: Tekst ujednolicony z dnia 17 sierpnia 2016 r., stanowiący załącznik do zarządzenia Rektora UG $n r 71 / R / 16$.

Regulamin, 2016b, Regulamin przyznawania świadczeń pomocy materialnej dla doktorantów w Uniwersytecie Gdańskim Tekst ujednolicony z dnia 16 sierpnia 2016 r., stanowiq̨cy załącznik do zarządzenia Rektora UG nr 72/R/16.

Sobowiak A. (red.), 2015, Raport nr 3/2015 Rady Głównej Nauki i Szkolnictwa Wyższego Studia doktoranckie i mobilność młodych naukowców, Warszawa.

Ustawa, 2005, Ustawa prawo o szkolnictwie wyższym (Dz. U. z 2005 r. Nr 164, poz. 1365 ze zm.).

Zarządzenie, 2016, Zarządzenie nr 87/R/15 Rektora Uniwersytetu Gdańskiego z dnia 28 lipca 2015 roku w sprawie przyznawania stypendium doktoranckiego w Uniwersytecie Gdańskim tekst ujednolicony $z$ dnia 17 sierpnia $2016 r$. 